TITLE:

\title{
Experimental macular edema induced by macular venule occlusion in monkey(Abstract_要 旨)
}

$\operatorname{AUTHOR}(\mathrm{S})$ :

leki, Yoshiaki

\section{CITATION:}

leki, Yoshiaki. Experimental macular edema induced by macular venule occlusion in monkey. 京都大学, 2003, 博士(医学)

ISSUE DATE:

2003-03-24

URL:

http://hdl.handle.net/2433/148694

RIGHT: 


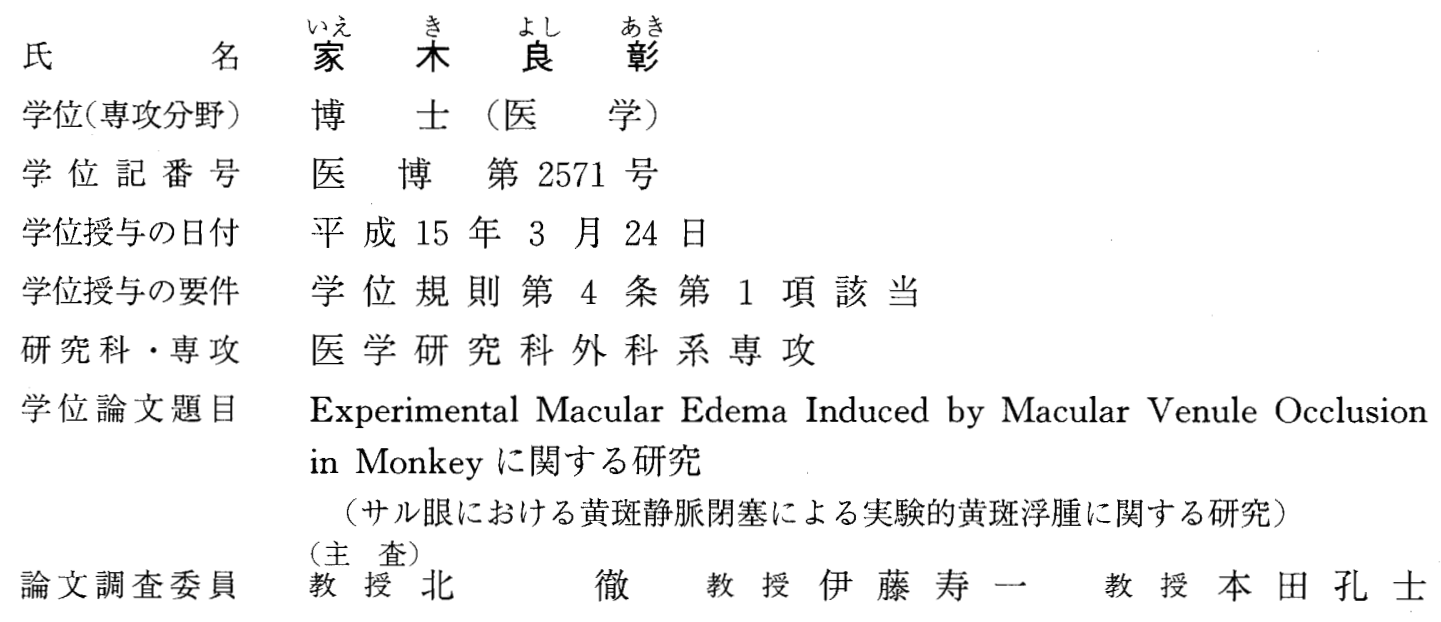

\section{論文内容の要旨}

【目的】黄斑静脈閉塞は網膜静脈閉塞症の 1 つの型であるが, その視力予後は黄斑浮腫や無血管野の出現によりばらつきが ある。なぜ黄斑浮腫が起きる症例と起きない症例があるのか？なぜ無血管野が出現したり出現しなかったりするのかとい うメカニズムははっきりと解明されていない。過去サルを用いた実験的網膜静脈閉塞の報告はあり，網膜浮腫，出血，無血 管野などは観察されていた。しかしなぜそれらが起きるときと起きないときがあるのかという検討は未だなされていない。 今回の実験ではカニクイザルの黄斑静脈を閉塞することで実験的黄斑浮腫の作成を試み, その時の血流の変化, 血管からの 漏出を検討した。

【方法】3 頭のカニクイザルの網膜静脈にダイレーザーを照射して下記のごとく静脈閉塞を作成した。実験 $1:$ 網膜静脈閉 塞。実験 2 : 黄斑静脈を 1 週間毎に閉塞していき, 黄斑浮腫が出現するまで続ける。実験 $3: 3$ 本の黄斑静脈を同時に閉塞。 黄斑浮腫は細隙灯顕微鏡検査及び OCT スキャナーで観察した。血流の流れる方向を観察するため白血球を蛍光染色してそ れを観察する方法 Acridine orange leukocyte fluorography（AOLF）と，血管からの造影剂漏出部位や無血管野を観察す るためにフルオレセイン蛍光眼底造影（FAG）をレーザー施行前と後に行った。

【結果】レーザー施行前の AOLFによる観察で, 黄斑動脈からの血流は fovea capillary ring 経由して上下どちらの黄斑 静脈にも流れうることがわかった。実験 1 では黄斑浮腫が発生せず, 白血球は対側静脈へと流れていた。造影剂は静脈側か ら漏出したがすぐに改善し, 無血管野にはならなかった。実験 2 では 3 本の上黄斑静脈を1週間毎に 1 本ずっ閉塞しても, 黄斑浮腫が発生せず, 白血球は下黄斑静脈へと流れていた。4 本目として下黄斑静脈を 1 本閉塞した時点で黄斑浮腫が発生 した。白血球の流れは極度に減少し, 停滞していた。その時最初は黄斑静脈側から造影剤漏出していたのが, やがて黄斑動 脈側からの漏出へと変化した。その後黄斑動脈閉塞にいたり無血管野の出現とともに黄斑浮腫は改善した。実験 3 ではすぐ に黄斑浮腫が出現し, 白血球の流れは極度に減少し, 停滞していた。最初から黄斑動脈側で造影剤漏出していたが, その後 無血管野を形成せずに黄斑浮腫は己蹇した。

【考察】サル眼に扔いて実験的黄斑浮腫を作成でき，3 種類の網膜変化の観察に OCT, AOLF, FAG は有用であった。白血 球の流れをもとに血流の変化を観察すると, 黄斑浮腫が出現しないときの血流は, 周辺の閉塞していない黄斑静脈（特に対 側）に代償的に流れていた。一方黄斑浮腫が出現したときは，血流は極度に減少し，停滞していた。残った静脈が代償的に 側副路として働く時は黄斑浮腫が発生しないが，それが overflowに耐えきれなくなると黄斑浮腫が発生すると考えられた。 黄斑浮腫が発生するかどうかは残った静脈の機能に依るということがわかった。造影済漏出部位が黄斑静脈側から黄斑動脈 側へと変化したのは，血管内圧が徐々に上昇していったためであることで説明可能であった。血管内圧の上昇が更に持続す ると，黄斑動脈が閉塞し，無血管野が出現すると考えられた。

【結論】サル眼の黄斑静脈閌塞を作成し実験的黄斑浮腫が誘発することができた。AOLFによる観察で, 黄斑浮腫ができる かできないかは，残っている閉塞していない静脈の側副路としての機能によることがわかった。血管内圧が徐々に上昇して 
いくことが無血管野の形成に関与していると考えられた。

\section{論文審 査の結 果の 要 旨}

網膜静脈閉塞症の視力予後は黄斑浮腫や無血管野の発生の有無により多様性がある。しかし，なぜ黄斑浮腫が発生したり しなかったりするのか，なぜ無血管野が発生したりしなかったりするのか，はっきりと解明されていない。本論文ではカニ クイザルを用い，網膜静脈の分枝である黄斑静脈を閉塞し，実験的黄斑浮腫を作成，その動態を観察することによって上記 の原因を解明しょうとした。

アクリジン白血球蛍光造影法を用いて, 静脈閉塞後の血流変化を観察した。閉塞を免れた静脈の機能が代償的に働いて, 血流が周辺の黄斑静脈を通って流出する様子が観察された時には, 黄斑浮腫が発生しなかった。残った静脈の機能が低下し, overflow 導出できない時には，血流が停滞し黄斑浮腫が発生した。

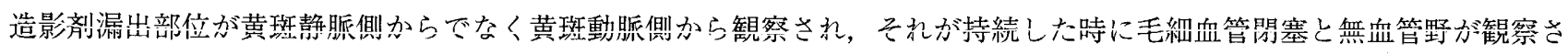
れた。このことから, 静脈閉塞後の血管内圧が徐々に上昇して毛細血管圧を越える状態が持続すると, 毛細血管が閉塞し無 血管野が発生すると考えられた。

これまでの網膜静脈閉塞による動物実験で高度の黄斑浮腫が誘発された報告はなく, 本論文は網膜静脈閉塞後の黄斑浮腫 の動物モデルを初めて報告したものである。

以上の研究は網膜静脈閉塞における黄斑浮腫や無血管野の発生のメカニズムの解明に貢献し, 臨床的にも重篤な視力低下 を来す黄斑浮腫の治療の発展に寄与するところが多い。

したがって，本論文は博士（医学）の学位諭文として価值あるものと認める。

なお，本学位授与申請者は，平成15年 1 月 6 日実施の論文内容とそれに関連した試問を受け，合格と認められたものであ る。 